\title{
A comparative study of sperm production in two species of Australian arid zone rodents (Pseudomys australis, Notomys alexis) with marked differences in testis size
}

\author{
E. J. Peirce and W. G. Breed \\ Department of Anatomical Sciences, University of Adelaide, Adelaide, South Australia, \\ 5005, Australia
}

The plains rat, Pseudomys australis, and the spinifex hopping mouse, Notomys alexis, show marked differences in the size of their testes and in the number of spermatozoa within the epididymides. In the present study, the dynamics of sperm production and the duration of sperm transit along the male excurrent ducts were compared between these two species. The durations of the cycle of the seminiferous epithelium, spermatogenesis and sperm transit were determined by tracking cells using autoradiography after $\left[{ }^{3} \mathrm{H}\right]$ thymidine incorporation. Daily sperm production was determined from counts of testicular spermatids after homogenization and further estimates of sperm transit were obtained by dividing sperm reserves within the various regions of the extratesticular ducts by the daily sperm production of the attached testis. In the plains rat, the mean duration of the cycle of the seminiferous epithelium was $\mathbf{1 1 . 2}$ days, the duration of spermatogenesis was 45 days, daily sperm production was
$2.6 \times 10^{7}$ spermatozoa per gram of testis and epididymal transit of spermatozoa took approximately 9 days (caput 0.8 days; corpus 1.5 days; cauda 6.5 days). In contrast, in the hopping mouse, the mean duration of the cycle of the seminiferous epithelium was 14 days, the duration of spermatogenesis was $\mathbf{5 6}$ days and daily sperm production per gram of testis was $<1.0 \times 10^{7}$. Epididymal transit of spermatozoa was completed in about 4 days (caput + corpus < 1 day; cauda 3 days); however, spermatozoa may be stored for an additional 1.5-2.0 days in the vas deferens. These results indicate that, in addition to small testes, the hopping mouse shows a low efficiency of sperm production, a relatively long duration of spermatogenesis and rapid passage of spermatozoa through the epididymis, all of which contribute to low epididymal sperm counts. These data are considered in relation to interspecific differences in sperm competition.

\section{Introduction}

In males, the number of viable spermatozoa available for fertilizing oocytes relates to the amount of spermproducing tissue and the rate of sperm production by the testes, as well as the duration of sperm transit and storage capacity of the extratesticular ducts. Although the size of the testis and especially the volume of the testis occupied by the seminiferous tubules play a major role in determining the absolute number of spermatozoa produced, the efficiency of sperm production is influenced by the duration of the cycle of the seminiferous epithelium and the capacity of developing germ cells to survive and complete spermatogenesis. Therefore, high sperm production per unit time is achieved by having relatively large testes composed of predominantly spermatogenic tissue, a short spermatogenic cycle, a high efficiency of spermatogenesis, or any combination of these factors. Similarly, the number of spermatozoa within the epididymis and vas deferens

Email: eleanor.peirce@adelaide.edu.au reflects not only the rate of sperm production, but also the duration of sperm transit, which in turn is influenced by the length and width of the duct and its storage capacity.

Among the conilurine rodents of Australia, there are marked differences in the size of the testes and the numbers of epididymal spermatozoa. The plains rat, Pseudomys australis, and the spinifex hopping mouse, Notomys alexis, are two closely related species of Australian rodents (Watts et al., 1992) which inhabit the arid zone, but nevertheless represent two extremes with respect to testes mass relative to body weight (Breed, 1982, 1986, 1997a; Peirce and Breed, 1989). Such differences in the size of the testes may relate, at least in part, to differences in intermale sperm competition and breeding system (Short, 1979; Harcourt et al., 1981; Kenagy and Trombulak, 1986). The relatively small testes of the hopping mouse are possibly due to low intermale sperm competition as a result of a single male breeding system. However, the social organization of hopping mice in the laboratory indicates group living, in which multiple matings at oestrus could sometimes occur (Breed and Washington, 1991). Tests set up to investigate this hypothesis did not reveal multiple paternity, 
although it was evident in the plains rat (Breed and Adams, 1992). In hopping mice, females are more aggressive than males, thus it has been suggested that, in the natural environment, the behaviour of the female, rather than that of the male, minimizes the chances of multiple matings at oestrus (Breed, 1990; Breed and Taylor, 2000). In cases where the intensity of sperm competition has influenced the numbers of spermatozoa produced in males of a particular species, it is possible that differences have also evolved in the dynamics and efficiency of sperm production and the duration of sperm transit. It has been shown that the organization of the testicular seminiferous epithelium varies between the plains rat and the hopping mouse (Peirce and Breed, 1987), but how this difference relates to the dynamics of sperm production and differences in the number of epididymal spermatozoa between the species is not known. Therefore, in the present study, the duration and efficiency of sperm production by the testes and the duration of sperm transit along the epididymides in these two species of Australian rodents were determined. In particular, comparisons were made between (i) the duration of the cycle of the seminiferous epithelium and that of spermatogenesis; (ii) daily sperm production and the efficiency of sperm production; and (iii) the duration of sperm transit along the epididymides.

\section{Materials and Methods}

\section{Animals}

Sexually mature male plains rats, Pseudomys australis, and spinifex hopping mice, Notomys alexis, aged 315 months, were obtained from colonies bred in the animal house of the Medical School, Adelaide University, or from local suppliers. For each species, groups of four or five males were housed together in standard rat or mouse cages under conditions of regulated temperature $\left(18-25^{\circ} \mathrm{C}\right)$ and lighting ( $12 \mathrm{~h}$ light:12 $\mathrm{h}$ dark). Animals were fed a diet of mouse pellets (Milling Industries, Mile End) supplemented twice a week with mixed seed, fresh apple and carrot, and water was available at all times. All experimental procedures were approved by The Animal Ethics Committee, Adelaide University.

\section{Duration of the cycle of the seminiferous epithelium}

Administration of $\left[{ }^{3} \mathrm{H}\right]$ thymidine and preparation of sections. Plains rats and hopping mice $(n=20$ per species) were given a single i.p. injection of [methyl${ }^{3} \mathrm{H}$ ]thymidine (specific activity $43 \mathrm{Ci} \mathrm{mmol}^{-1}$; Amersham, Buckinghamshire) at a dose rate of $1.0-1.5 \mu \mathrm{Ci} \mathrm{g}^{-1}$ body weight. These animals were subsequently killed by an overdose of pentobarbitone sodium (Nembutal, AbbottCeva Chemicals, Hornsby, NSW) administered i.p. or carbon dioxide asphyxiation at intervals as follows. Two plains rats were killed at each of $1 \mathrm{~h}, 1$ day $1 \mathrm{~h}, 3$ days $22 \mathrm{~h}, 7$ days $1 \mathrm{~h}, 9$ days $1 \mathrm{~h}$ and 12 days $4 \mathrm{~h}$; three animals were killed at 13 days $1 \mathrm{~h}$; and one animal was killed at each of 4 days $1 \mathrm{~h}, 5$ days $1 \mathrm{~h}, 15$ days, 15 days $1 \mathrm{~h}$ and 16 days $1 \mathrm{~h}$ after $\left[{ }^{3} \mathrm{H}\right]$ thymidine administration. Three hopping mice were killed at $1 \mathrm{~h}$, two animals were killed at each of 3 days $22 \mathrm{~h}, 7$ days $1 \mathrm{~h}, 8$ days, 12 days $4 \mathrm{~h}$, 13 days $1 \mathrm{~h}, 14$ days $1 \mathrm{~h}, 15$ days and 16 days $1 \mathrm{~h}$, and one animal at 26 days after $\left[{ }^{3} \mathrm{H}\right]$ thymidine administration.

After the animals were killed, testes were removed, weighed and fixed by immersion in either TEM fixative $(3 \%(\mathrm{w} / \mathrm{v})$ formaldehyde and $3 \%(\mathrm{w} / \mathrm{v})$ glutaraldehyde) or Bouin's solution for $24 \mathrm{~h}$. The tissue was processed using standard methods, embedded in Paraplast and sectioned at $5 \mu \mathrm{m}$. Sections were hydrated, coated by dipping in Kodak NTB-2 nuclear track emulsion (Eastman Kodak, Rochester, NY) or Illford K2 nuclear research emulsion (Illford Australia, Mt Waverley, Victoria) diluted with an equal volume of double-distilled water, and dried flat for $24 \mathrm{~h}$ at $20^{\circ} \mathrm{C}$. The sections were transferred to light-tight black plastic boxes containing desiccant and were stored at $4^{\circ} \mathrm{C}$ in a refrigerator. After 4-12 weeks of exposure to the emulsion, batches of slides were developed with Kodak Dektol developer (Kodak Australasia, Coburg, Victoria), fixed in $30 \%(\mathrm{w} / \mathrm{v})$ sodium thiosulphate and stained with either Harris' haematoxylin or haematoxylin and eosin.

Frequency of cycle stages. The relative frequency of each stage of the cycle of the seminiferous epithelium was determined from plastic-embedded toluidine blue-stained sections of testes from 12 plains rats and 14 hopping mice. The cycle of the seminiferous epithelium was divided into 11 stages in the plains rat and eight stages in the hopping mouse, according to differences in the acrosomal and nuclear morphology of the younger generation of spermatids. The criteria used to determine the stages of the cycle were modified from those described by Leblond and Clermont (1952) and Russell et al. (1990) for the laboratory rat, to take into account species differences in the degree of spread of the acrosome over the nucleus and the elongation and shape of the spermatid head. Sections of testes were examined at either $\times 400$ or $\times 1000$ magnification. Each crosssectional profile of a seminiferous tubule was classified according to the stage of the cycle observed. For each animal, approximately 200 tubular cross-sections from at least four testicular locations were scored, a total of 2059 seminiferous tubules for the plains rat and 3157 seminiferous tubules for the hopping mouse. In cases in which crosssections of seminiferous tubules of the hopping mouse contained more than one stage of the cycle (see Peirce and Breed, 1987), each stage was assigned a score corresponding to the fraction of the cross-sectional profile occupied by that stage. For each species, the mean frequency ( \pm SD) of each stage of the cycle of the seminiferous epithelium was determined by dividing the count for that stage by the total number of seminiferous tubule profiles counted.

Analysis of cycle duration. The duration of the cycle of the seminiferous epithelium was determined according to the method of Clermont and Trott (1969). For each time 
interval after $\left[{ }^{3} \mathrm{H}\right]$ thymidine administration, the position within the cycle of the most advanced labelled type of cell was recorded, and the duration of the cycle was estimated as follows:

duration of one cycle $=x / y$

where $x=$ known time interval between the two appearances of labelled cells at times $A$ and $B ; y=$ relative proportion of one cycle travelled by the labelled cells in $x$ days (that is, the sum of the stage frequencies between the two appearances of labelled cells at times $A$ and $B$ ).

\section{Determination of daily sperm production}

Daily sperm production per animal and daily sperm production per gram of testicular tissue were determined using the testicular homogenization method (Almquist and Amann, 1961; Amann, 1970a). Five plains rats and five hopping mice were given a single i.p. injection of $\left[{ }^{3} \mathrm{H}\right]$ thymidine $\left(2 \mu \mathrm{Ci} \mathrm{g}^{-1}\right.$ body weight) and one animal of each species was killed after 31 days, 31 days $17 \mathrm{~h}$, 32 days $12 \mathrm{~h}, 35$ days $5 \mathrm{~h}$ and 37 day to determine the time divisor for each species. Testes were removed and weighed, and one testis from each animal was subsequently fixed, processed, embedded in Paraplast, sectioned at $5 \mu \mathrm{m}$ and mounted on to glass slides. The other testis from each animal was homogenized in 10-50 ml homogenizing fluid $(150 \mathrm{mmol} \mathrm{NaCl} \mathrm{I-1,0.05 \%} \mathrm{(v/v)}$ Triton-X100, $3.8 \mathrm{~mol} \mathrm{NaN}_{3} \mathrm{I}^{-1}$; Amann and Lambiase, 1969) for 2 min using an Ultra-turrax TP18-10 blender (Labortechnik, Staufen). Smears of each homogenate were prepared and fixed in a 1:1 solution of ether:ethanol for $30 \mathrm{~min}$. Slides of both the tissue sections and homogenate smears were processed for autoradiography as described earlier. The time divisor was calculated as the sum of the relative durations of the stages of the seminiferous epithelium cycle as observed in tissue sections, which corresponded to the labelled resistant spermatid nuclei in testicular homogenates of the same animal, multiplied by the duration of one cycle of the seminiferous epithelium.

Sperm production was determined for 12 plains rats and 18 hopping mice, including the animals used to determine the time divisors. After animals were killed, testes were removed and weighed before one or both testes were homogenized in 10-50 ml homogenizing fluid as described earlier. Elongated spermatid nuclei that were resistant to homogenization were counted in ten haemocytometer chambers each of $0.1 \mu \mathrm{l}$ and an average count per volume was determined. The number of spermatid nuclei per testis sample was calculated as the average haemocytometer count, multiplied by the total homogenate volume and any dilution factor of the original homogenate volume before counting. Sperm production per gram of testis was determined by dividing the total sperm count in the homogenate by the mass of the testicular tissue homogenized. Spermatid counts per animal or per gram of testicular tissue were converted to daily sperm production per animal or per gram of testicular tissue by dividing by a time divisor of 4.4 days for the plains rat and 6.9 days for the hopping mouse (see results section for the derivation of these values).

\section{Determination of sperm transit}

The time taken for spermatozoa to travel along the epididymis in the plains rat and the hopping mouse was determined by tracking the progress of labelled spermatozoa through the various regions of the duct, and by dividing the sperm reserves within a particular region of the duct by the rate of daily sperm production of the attached testis.

Tracking spermatozoa by autoradiography. A single i.p. injection of $70 \mu \mathrm{Ci}$ or $40 \mu \mathrm{Ci}$ [methyl- ${ }^{3} \mathrm{H}$ ]thymidine (dose of $1.0-1.5 \mu \mathrm{Ci} \mathrm{g}^{-1}$ body weight; specific activity $43 \mathrm{Ci}$ $\mathrm{mmol}^{-1}$; Amersham) was administered to each of 19 plains rats and 19 hopping mice, respectively. One animal of each species was subsequently killed every 2 days from day 26 to day 64 after $\left[{ }^{3} \mathrm{H}\right]$ thymidine administration. Reproductive tracts were removed and one side of the tract with its corresponding testis was fixed in Bouin's solution for $24 \mathrm{~h}$, processed, embedded in Paraplast and sectioned at $5 \mu \mathrm{m}$. The other side of the reproductive tract was divided into caput, corpus and cauda epididymides, and vas deferens, and smears of the luminal contents were prepared and fixed for $1 \mathrm{~h}$ in formaldehyde vapour. Both sections and smears were coated with nuclear emulsion and exposed for 6-12 weeks, after which time the batches of slides were developed, fixed and stained with Harris's haematoxylin. Stained slides and smears were analysed to determine the position of labelled spermatozoa within the male tract.

Transit time as determined from extragonadal sperm reserves and daily sperm production. Testes and reproductive tracts were removed from plains rats $(n=5)$ and hopping mice $(n=6)$. The testes and tracts were weighed and daily sperm production per testis was determined as described earlier. In the plains rat, the left and right hand sides of the excurrent duct system were divided into caput, corpus and cauda epididymides. In the hopping mouse, the epididymis was divided into caput plus corpus and cauda segments. The vas deferens was divided into 'epididymal' and 'urethral' segments at the site at which the diameter of the duct increased. Each duct segment was minced into a known volume of physiological saline and agitated gently for $15 \mathrm{~min}$ to ensure the release of spermatozoa from the tissue fragments. The resulting suspensions were diluted as necessary and spermatozoa were counted in ten haemocytometer chambers each of $0.1 \mu \mathrm{l}$. The number of spermatozoa in each duct segment was calculated by multiplying the average sperm count by the initial volume of the suspension and any dilution factor. The sperm transit time through the various segments of the extratesticular 
Table 1. Relative frequency (mean $\pm \mathrm{SD}$ ) and duration of the stages of the cycle of the seminiferous epithelium in the plains rat (Pseudomys australis) $(n=12)$ and the hopping mouse (Notomys alexis) $(n=14)$

\begin{tabular}{|c|c|c|c|c|c|c|c|c|c|c|c|}
\hline & \multicolumn{11}{|c|}{ Stage of the seminiferous cycle } \\
\hline & I & II & III & IV & V & $\mathrm{VI}$ & VII & VIII & IX & $X$ & $X I$ \\
\hline \multicolumn{12}{|l|}{ Plains rat } \\
\hline Frequency (\%) & $\begin{array}{r}18.60 \\
\pm 3.49\end{array}$ & $\begin{array}{c}5.02 \\
\pm 2.44\end{array}$ & $\begin{array}{c}7.60 \\
\pm 1.95\end{array}$ & $\begin{array}{c}5.67 \\
\pm 2.51\end{array}$ & $\begin{array}{l}15.72 \\
\pm 4.54\end{array}$ & $\begin{array}{c}6.68 \\
\pm 2.21\end{array}$ & $\begin{array}{c}6.50 \\
\pm 2.26\end{array}$ & $\begin{array}{c}7.95 \\
+3.06\end{array}$ & $\begin{array}{l}11.17 \\
\pm 3.08\end{array}$ & $\begin{array}{c}8.90 \\
\pm 3.36\end{array}$ & $\begin{array}{c}6.19 \\
\pm 4.40\end{array}$ \\
\hline Duration $^{\mathrm{a}}$ (days) & 2.08 & 0.56 & 0.85 & 0.64 & 1.76 & 0.75 & 0.73 & 0.89 & 1.25 & 1.00 & 0.69 \\
\hline \multicolumn{12}{|l|}{ Hopping mouse } \\
\hline Frequency (\%) & $\begin{array}{r}14.95 \\
\pm 2.73\end{array}$ & $\begin{array}{c}6.95 \\
\pm 1.72\end{array}$ & $\begin{array}{c}10.57 \\
\pm 2.98\end{array}$ & $\begin{array}{l}24.51 \\
\pm 4.21\end{array}$ & $\begin{array}{l}11.41 \\
\pm 0.10\end{array}$ & $\begin{array}{c}9.75 \\
\pm 2.22\end{array}$ & $\begin{array}{l}13.53 \\
\pm 4.06\end{array}$ & $\begin{array}{c}8.32 \\
\pm 1.87\end{array}$ & & & \\
\hline Duration $^{b}$ (days) & 2.09 & 0.98 & 1.48 & 3.43 & 1.60 & 1.37 & 1.89 & 1.16 & & & \\
\hline
\end{tabular}

aDuration of each stage based on a cycle duration of 11.2 days.

b Duration of each stage based on a cycle duration of 14.0 days.

ducts was determined by dividing the number of spermatozoa in the segment by the daily sperm production of the attached testis.

\section{Results}

\section{Duration of the cycle of the seminiferous epithelium}

The frequencies and durations of the 11 stages of the cycle of the seminiferous epithelium in the plains rat and the eight stages of the cycle in the hopping mouse are shown (Table 1).

In the plains rats, autoradiography showed that the most developmentally advanced labelled germ cells at $1 \mathrm{~h}$ after $\left[{ }^{3} \mathrm{H}\right]$ thymidine administration were preleptotene and leptotene primary spermatocytes at stages $\mathrm{V}-\mathrm{VI}$ of the cycle of the seminiferous epithelium. The most advanced cells showing labelling at 7 days $1 \mathrm{~h}$ after $\left[{ }^{3} \mathrm{H}\right]$ thymidine administration were pachytene primary spermatocytes of stages III-IV, and at 12 days $4 \mathrm{~h}$ were the pachytene primary spermatocytes of stages VI-VII. Similarly, the most advanced labelled types of cell were determined in the testes of animals killed at other time intervals after $\left[{ }^{3} \mathrm{H}\right]$ thymidine administration (individual data not provided). On the basis of the progression, within known time intervals, of the labelled cells through the cycle of the seminiferous epithelium, the duration of one cycle of the seminiferous epithelium in the plains rat was estimated to be $11.2 \pm 1.3$ days (mean $\pm \mathrm{SD}$; range 6.6-12.1 days).

In the hopping mouse, the most developmentally advanced cells showing labelling at $1 \mathrm{~h}$ after $\left[{ }^{3} \mathrm{H}\right]$ thymidine administration were the leptotene primary spermatocytes of stage $V$. After 7 days, the label had progressed to the pachytene primary spermatocytes of stage 1 and after 15 days to the pachytene primary spermatocytes of stage VI. By day 26 after labelling, the most advanced labelled cells were the round spermatids of stage IV. These data and data from other time intervals (not shown) gave a mean duration of the cycle of the seminiferous epithelium in the hopping mouse of $14.0 \pm 1.5$ days (range 12.4-18.5 days).

The lifespans of the different types of germ cell were determined from the duration of the cycle of the seminiferous epithelium and the relative frequencies of individual stages of the cycle. For the plains rat, the lifespan of primary spermatocytes was 17.9 days, of secondary spermatocytes was 0.7 days, of spermatids with round nuclei was 7.0 days and of spermatids with elongated nuclei was 10.8 days. For the hopping mouse, the lifespan of primary spermatocytes was 24.4 days, of secondary spermatocytes was 1.2 days, of round spermatids was 10.3 days and of elongated spermatids was 12.6 days.

\section{Daily sperm production}

Time divisor. In the plains rat, spermatid nuclei resistant to testicular homogenization corresponded to the elongated spermatids of stages II-VI of the cycle of the seminiferous epithelium. These stages represent $39.8 \%$ of one cycle of the seminiferous epithelium (Table 1). Since the duration of one cycle is 11.2 days, the total duration of stages II-VI is $0.3978 \times 11.2$ days $=4.4$ days, which was used as the time divisor.

In the hopping mouse, spermatid nuclei resistant to testicular homogenization corresponded to the elongated spermatids of stages I-IV of the cycle of the seminiferous epithelium. Although in the tissue sections approximately $50 \%$ of the elongated spermatids in stage I did not show labelling with $\left[{ }^{3} \mathrm{H}\right]$ thymidine, no unlabelled spermatid nuclei were observed in the corresponding testicular homogenate, indicating that not all stage I elongated spermatids are resistant to homogenization. Therefore, the time divisor was estimated to correspond to the duration of 
Table 2. Body and testes masses and sperm production in the plains rat (Pseudomys australis), hopping mouse (Notomys alexis) and laboratory rat

\begin{tabular}{|c|c|c|c|}
\hline Characteristic & $\begin{array}{l}\text { Plains rat } \\
(n=17)\end{array}$ & $\begin{array}{l}\text { Hopping mouse } \\
\quad(n=18)\end{array}$ & $\begin{array}{l}\text { Laboratory rat } \\
\qquad(n=10)\end{array}$ \\
\hline \multicolumn{4}{|l|}{ Masses (g) } \\
\hline Body & $48.8 \pm 8.3$ & $32.0 \pm 3.6$ & $500.0^{b}$ \\
\hline Paired testes & $1.57 \pm 0.26$ & $0.052 \pm 0.017$ & 3.54 \\
\hline Ratio testes:body (\%) & 3.21 & 0.16 & 0.71 \\
\hline \multicolumn{4}{|l|}{ Sperm production $\left(10^{6}\right)$} \\
\hline Spermatids per paired testes & $177.6 \pm 51.0$ & $3.6 \pm 1.7$ & 446.6 \\
\hline Spermatids per gram of testis & $113.9 \pm 29.0$ & $67.9 \pm 16.4$ & 126.2 \\
\hline Daily sperm production per animal & $40.4 \pm 11.6$ & $0.5 \pm 0.2$ & 70.8 \\
\hline $\begin{array}{l}\text { Daily sperm production per gram } \\
\text { of testis }\end{array}$ & $25.9 \pm 6.6$ & $9.8 \pm 2.4$ & 21.1 \\
\hline Time divisor (days) & 4.4 & 6.9 & 6.3 \\
\hline
\end{tabular}

Values are means $\pm \mathrm{SD}$; laboratory rat means only.

a Laboratory rat data are based on values given in Johnson et al. (1980a).

bMean body weight of laboratory rats taken from Kenagy and Trombulak (1986).

stages II-IV plus $50 \%$ of the duration of stage I, or $49.5 \%$ of one cycle of the seminiferous epithelium (see Table 1). Since the duration of the cycle is 14.0 days in the hopping mouse, the time divisor was $0.4951 \times 14.0$ days $=6.9$ days.

Numbers of spermatids per animal and daily sperm production. A summary of sperm production parameters in the plains rat and the hopping mouse, together with published data for the laboratory rat is provided (Table 2). In the plains rat, the number of spermatids resistant to homogenization in both testes ranged from 0.52 to $2.41 \times 10^{8}$. This range represented a daily sperm production per animal of between 1.18 and $5.48 \times 10^{7}$. Paired testes mass ranged from 1.06 to $1.97 \mathrm{~g}$, giving a daily sperm production per gram of testis of between 0.72 and $3.49 \times 10^{7}$. However, only one animal produced $<2.1 \times 10^{7}$ spermatozoa per gram of testis per day $(n=17)$. In the hopping mouse, paired testis mass ranged from 28.9 to $80.0 \mathrm{mg}$. The number of spermatids per animal resistant to testicular homogenization varied from 1.5 to $7.4 \times 10^{6}$, daily sperm production per gram of testis from 0.73 to $1.65 \times 10^{7}$, and daily sperm production per animal from 0.22 to $1.07 \times 10^{6}$. Only two of 18 animals produced $>1 \times 10^{6}$ spermatozoa per day. On the basis of mean species values (Table 2), plains rats produce about 80 times more spermatozoa per day than hopping mice.

\section{Duration of sperm transit through the excurrent ducts}

Plains rats. Labelled spermatozoa were first observed in the caput epididymidis 36 days after $\left[{ }^{3} \mathrm{H}\right]$ thymidine administration. Although no labelling was observed in the epididymides of animals killed 26, 28, 30, 32 or 34 days after $\left[{ }^{3} \mathrm{H}\right]$ thymidine administration, in the animals killed at
32 and 34 days, labelled spermatids in stages $\mathrm{V}$ and $\mathrm{VI}$ of the spermatogenic cycle surrounded the lumina of seminiferous tubules just before their release from the epithelium. Labelled spermatozoa were present throughout the corpus epididymidis by day 38 and were first observed in the cauda epididymidis proximal to the caudal flexure by day 42 and distal to the flexure by day 48 . Hence, there is an interval of about 12 days between the occurrence of labelled spermatozoa in the caput and lower portions of the cauda epididymides. The average time for spermatozoa to pass through the epididymis, as determined from extragonadal sperm reserves and daily sperm production (see Table 3), was 0.8 days for the caput epididymidis, 1.5 days for the corpus epididymidis and 6.5 days for the cauda epididymis. Therefore, in sexually rested plains rats, the average time for spermatozoa to travel through the epididymis was 8.8 days.

Hopping mice. Testis sections from animals killed on day 40 and day 42 after $\left[{ }^{3} \mathrm{H}\right]$ thymidine administration showed labelled elongate spermatids surrounding the lumina of the seminiferous tubules at stages III-IV. Labelled spermatozoa were first observed in the epididymis on day 42 after $\left[{ }^{3} \mathrm{H}\right]$ thymidine administration. These spermatozoa were present predominantly within the caput and corpus epididymides, although occasionally labelled spermatozoa were observed in the cauda epididymidis. A larger number of spermatozoa were labelled in the cauda epididymidis by day 44 and a few labelled spermatozoa were observed in sections of the vas deferens immediately adjacent to the epididymis on day 46. Both sections and smears of the vas deferens contained labelled spermatozoa in all animals killed from day 48 to day 70 . Hence the minimum time taken by spermatozoa to pass through the epididymis is about 4-6 days. Average sperm transit time, as determined 
Table 3. Sperm reserves and transit time of spermatozoa through the extragonadal ducts of sexually rested plains rats (Pseudomys australis) and hopping mice (Notomys alexis)

\begin{tabular}{lcc}
\hline Characteristic & $\begin{array}{c}\text { Plains rat } \\
(n=5)\end{array}$ & $\begin{array}{c}\text { Hopping mouse } \\
(n=6)\end{array}$ \\
\hline Sperm reserves $\left(10^{6}\right)$ & & \\
$\quad$ Caput epididymidis & $17.6 \pm 6.5$ & $0.20 \pm 0.17^{\mathrm{b}}$ \\
Corpus epididymidis & $34.5 \pm 6.1$ & $0.20 \pm 0.17$ \\
Cauda epididymidis & $149.0 \pm 67.2$ & $0.22 \pm 0.25$ \\
Proximal vas deferens & - & $0.15 \pm 0.14$ \\
Distal vas deferens & - & \\
Duration of sperm transit (days) ${ }^{\mathrm{a}}$ & $0.8 \pm 0.2$ & $0.9 \pm 0.4^{\mathrm{b}}$ \\
Caput epididymidis & $1.5 \pm 0.2$ & $3.1 \pm 1.2$ \\
Corpus epididymidis & $6.5 \pm 2.8$ & $0.9 \pm 0.8$ \\
Cauda epididymidis & - & $0.7 \pm 0.6$ \\
Proximal vas deferens & - & \\
Distal vas deferens & & \\
\hline
\end{tabular}

Values are means \pm SD.

aSperm transit determined by dividing extragonadal sperm reserves by daily sperm production of the attached testis.

bValues for caput and corpus epididymides.

by dividing sperm stores by daily sperm production, was 0.9 days for the caput plus corpus epididymides, 3.1 days for the cauda epididymidis and 1.6 days for the entire vas deferens, giving a total sperm transit time of approximately 5.6 days in sexually rested individuals (Table 3 ).

\section{Discussion}

This study indicates that factors in addition to testis mass contribute to the marked differences in sperm output between two species of arid zone Australian conilurine rodents, the plains rat and the hopping mouse. In the hopping mouse, which has extremely small testes, there is a relatively extended cycle of the seminiferous epithelium, a lower efficiency of sperm production and a faster transit of spermatozoa through the extratesticular ducts. Consequently the recovery of spermatozoa from the epididymides is much lower compared with that of the plains rat. Furthermore, in the hopping mouse, a significant number of spermatozoa also occur in the vasa deferentia of some individuals.

In most rodent species for which data are available, the duration of the cycle of the seminiferous epithelium is between 8 and 13 days (Clermont et al., 1959; Clermont and Trott, 1969; Schuler and Gier, 1976; Noller et al., 1977; Sinha Hikim et al., 1985; Rosiepen et al., 1994), although it ranges in duration from 6.7 days in the bank vole (Grocock and Clarke, 1976) to 17.0 days in the Chinese hamster (Oud and de Rooij, 1977). Therefore, the 11.2 day cycle observed in the plains rat is average for the rodents that have been studied, including the common laboratory murid species; but the 14 day cycle of the hopping mouse is relatively long, and is the longest cycle recorded for any species of murine rodent.
If the beginning of spermatogenesis is considered as the first division of differentiating spermatogonia (Clermont, 1972), in both the plains rat and the hopping mouse, approximately four cycles of the seminiferous epithelium elapse between the initial spermatogonial division and spermiation. Thus, the duration of spermatogenesis is approximately 45 days in the plains rat and 56 days in the hopping mouse. In mammalian species, the duration of the meiotic phase of spermatogenesis (including the meiotic divisions) compared with that of spermiogenesis is generally similar (Courot et al., 1970). In the laboratory mouse, the duration of the two phases are about equal, but in the laboratory rat spermiogenesis takes about 5 days more than the meiotic prophase (Russell et al., 1990). The plains rat is similar to the laboratory mouse in that both phases of spermatogenesis have a similar duration (17.9 compared with 17.8 days); however, in the hopping mouse, the duration of spermiogenesis is shorter than that of meiosis (22.9 days versus 25.6 days for meiosis), although the lifespan of the round spermatids ( 10.3 days) is about 3 days longer than that in the plains rat ( 7 days). These findings confirm previous conclusions of differences in the timing of spermatogenic events between these two species of Australian rodent (Peirce and Breed, 1987).

In addition to the size of the testes, the efficiency of spermatogenesis also influences the number of spermatozoa produced by an individual. Sperm production, expressed as daily sperm production per gram of testicular tissue, is an indicator of the efficiency of spermatogenesis. Spermatogenic efficiency in mammals, as measured by daily sperm production per gram of testis, varies from about $2.65 \times 10^{7}$ in rabbits (Orgebin-Crist, 1968) to $<6 \times 10^{6}$ in humans (Amann and Howards, 1980; Johnson et al., 1980a,b, 1981), and most species for which 
data have been obtained produce $>1.9 \times 10^{7}$ spermatozoa per gram of testis per day (Gebauer et al., 1974; Robb et al., 1978; Okwun et al., 1996). Therefore, a mean daily sperm production per gram of testis of $2.59 \times 10^{7}$ in the plains rat indicates a highly efficient production of spermatozoa, similar to that of the laboratory rat, whereas the value of $9.8 \times 10^{6}$ spermatozoa per gram of testis per day in the hopping mouse indicates a relatively low efficiency of sperm production.

Although the comparative values of daily sperm production for plains rats and hopping mice given above take into account absolute differences in the size of the testis, it is assumed that the relative composition of the testes is similar between species. However, this is not the case, as seminiferous tubules make up about $94 \%$ of the total testicular volume in the plains rat, but account for only about $85 \%$ of total testicular volume in the hopping mouse (Breed, 1982; Peirce and Breed, 1990). Even if this species difference in the proportion of seminiferous tubular tissue is taken into account, the efficiency of sperm production in the plains rat, which has a daily sperm production per gram of seminiferous tubule of $2.74 \times 10^{7}$ is about twice that of the hopping mouse $\left(1.16 \times 10^{7}\right.$ sperm g-1 $^{-1}$ seminiferous tubule). Observations of the organization of the seminiferous epithelium (Peirce and Breed, 1987), together with qualitative observations on the incidence of degenerating germ cells and preliminary investigations of the ratios of various germ cell maturational stages:Sertoli cells (Peirce and Breed, 1998), indicate that a greater germ cell loss occurs in the hopping mouse during the late meiotic prophase and meiotic divisions.

Transit of spermatozoa through the epididymis in the plains rat takes about 9 days, which falls within the 8-14 day range reported for most other mammalian species (Rowley et al., 1970; Amann et al., 1976), whereas in the hopping mouse, sperm transit is completed in about 4 days. The rapid passage of spermatozoa through the caput and corpus epididymides, which takes $<1$ day, provides only minimum exposure of spermatozoa to the epididymal environment that is normally implicated in post-testicular maturation (Bedford, 1966, 1967; OrgebinCrist, 1967). This finding indicates that maturation of spermatozoa in the hopping mouse occurs rapidly in the upper regions of the epididymis, a possibility that needs to be investigated.

The duration of transit (= time of storage) of spermatozoa through the cauda epididymidis and vas deferens, particularly in sexually rested individuals, may relate to the maximum period that spermatozoa retain viability in the male reproductive tract. Sperm viability, in turn, may be dependent on the epididymal microenvironment to which the spematozoa are exposed. At present, there is no information on the composition of the epididymal luminal fluid and its influence on sperm viability in either the plains rat or hopping mouse. Thus, any possible influences of epididymal environment on the duration of sperm storage remain to be elucidated. An alternative explanation for the differences in the duration of sperm transit through the cauda epididymidis relates to the length and width of the duct. Other studies have indicated a luminal diameter of 200-600 $\mu \mathrm{m}$ for the cauda epididymidis of the plains rat, whereas that of the hopping mouse is 70-190 $\mu \mathrm{m}$, even in sexually rested individuals in which sperm reserves are at a maximum. Similarly, the overall length of the epididymal duct is about 13-15 cm in the hopping mouse compared with $60-70 \mathrm{~cm}$ in a rodent of a similar size, the laboratory mouse (Breed, 1986; Peirce and Breed, 1989). A reduced capacity for sperm storage may, therefore, result in the more rapid passage of spermatozoa through the cauda epididymidis in the hopping mouse and may also account for the greater proportion of sperm reserves in the vas deferens of some individuals.

Within a species, the small differences between the duration of sperm transit obtained by tracking the progression of labelled spermatozoa through the duct and that determined from sperm reserves divided by daily sperm production may relate to limitations in methodology. The tracer used in the present study, $\left[{ }^{3} \mathrm{H}\right]$ thymidine, is incorporated into the DNA of several generations of spermatogonia as well as into preleptotene primary spermatocytes. Thus several successive waves of labelled spermatozoa will enter the epididymis, but only the initial appearance of labelled spermatozoa within a region will provide a reliable indication of sperm transit time. The 2 day sampling interval used in the present study prevented an accurate determination of how rapidly spermatozoa moved through the caput and corpus epididymides. This was particularly apparent in the hopping mouse, since within a 2 day interval the front of labelling advanced from spermatids at the point of release from the testicular seminiferous epithelium to spermatozoa in the cauda epididymidis. In addition, data on advancement of the label front based on comparisons between individuals assume that spermatozoa are invariably released from the testis at the same time, although this may not be the case (see Amann and Lambiase, 1969; Amann, 1970b). In the plains rat, release of labelled spermatozoa from the seminiferous epithelium and their subsequent appearance in the caput epididymidis was expected to occur about 33.6 days after $\left[{ }^{3} \mathrm{H}\right]$ thymidine administration because three cycles of the seminiferous epithelium, each of 11.2 days, occur between incorporation of the label into preleptotene spermatocytes and spermiation. However, smears and sections of epididymis from animals killed on day 34 did not contain labelled spermatozoa and the first appearance of labelled spermatozoa in the epididymis was not observed until day 36 after $\left[{ }^{3} \mathrm{H}\right]$ thymidine administration.

Estimates of transit time derived from extragonadal sperm reserves and daily sperm production are based on the assumption that all spermatozoa leaving the testis are ejaculated and resorption of spermatozoa by the ducts during transit is negligible. This assumption is supported by the finding that little phagocytosis of spermatozoa by the epididymal epithelium takes place after vasectomy in a 
variety of species (Bedford, 1975). However, the second assumption on which estimations of transit time are based, that spermatozoa travel through the epididymis at a constant speed, may not be valid because it has been shown that spermatozoa located peripherally in the duct progress more rapidly than centrally located spermatozoa (OrgebinCrist, 1965). This results in a mixing, particularly in the cauda epididymidis, of sperm populations that have entered the epididymis from the testis at different times. Hence, it is likely that some spermatozoa pass through the cauda epididymidis more rapidly than others and consequently there is the potential for over- or underestimating transit time depending on the degree of mixing of the sperm population.

In conclusion, this study has shown that, in addition to a very small relative testes mass, the spinifex hopping mouse, Notomys alexis, also shows divergent features of sperm production. If a reduction in, or absence of, intermale sperm competition is one of the key factors that has resulted in the relatively small testes size in this species, it is likely that this factor has also brought about a reduction in the efficiency and rate of germ cell maturation, resulting in the evolution of an extended duration of the cycle of the seminiferous epithelium and depressed efficiency of sperm production. Furthermore, observations on sperm morphology in the cauda epididymides of this species show that, unlike in the plains rat, there is a remarkable degree of pleiomorphism (Breed and Sarafis, 1983; Suttle et al., 1988; Breed, 1997b). The nature of the selective pressures that have brought about the evolution of the divergent male reproductive anatomy in Notomys, and how they have operated on the reproductive system are not known. However, the findings from this study show that the evolution of the relatively small testes mass correlates with inefficient production of spermatozoa. It remains to be determined how natural selection operates on such a complex system as sperm production in male mammals. These two species of closely related arid zone rodents of Australia may be useful models for probing these questions.

The authors wish to thank Chris Leigh for technical advice and assistance. Part of this research was funded by a small ARC grant and a University of Adelaide Medical Faculty B1 grant.

\section{References}

Almquist JO and Amann RP (1961) Reproductive capacity of dairy bulls. II. Gonadal and extra-gonadal sperm reserves as determined by direct counts and depletion trials; dimensions and weight of genitalia Journal of Dairy Science 44 1668-1678

Amann RP (1970a) Sperm production rates. In The Testis pp 433-482 Eds AD Johnson, WR Gomes and NL Vandemark. Academic Press, New York

Amann RP (1970b) The male rabbit. IV. Quantitative testicular histology and comparisons between daily sperm production as determined histologically and daily sperm output Fertility and Sterility 21 662-672

Amann RP and Howards SS (1980) Daily spermatozoal production and epididymal spermatozoal reserves of the human male Journal of Urology $124211-215$
Amann RP and Lambiase JT (1969) The male rabbit. III. Determination of daily sperm production by means of testicular homogenates Journal of Animal Science 28 369-374

Amann RP, Johnson L, Thompson DL and Pickett BW (1976) Daily spermatozoal production, epididymal spermatozoal reserves and transit time of spermatozoa through the epididymis of the rhesus monkey Biology of Reproduction 15 586-592

Bedford JM (1966) Development of the fertilizing ability of spermatozoa in the epididymis of the rabbit Journal of Experimental Zoology 163 319-330

Bedford JM (1967) Effect of duct ligation on the fertilizing ability of spermatozoa in the epididymis of the rabbit Journal of Experimental Zoology 166 271-282

Bedford JM (1975) Maturation, transport and fate of spermatozoa in the epididymis. In Handbook of Physiology, Vol. V. Endocrinology. Section 7, Male Reproductive System pp 307-317 Eds DW Hamilton and RO Greep. American Physiological Society, Washington DC

Breed WG (1982) Morphological variation in the testes and accessory sex organs of Australian rodents in the genera Pseudomys and Notomys. Journal of Reproduction and Fertility 66 607-613

Breed WG (1986) Comparative morphology and evolution of the male reproductive tract in the Australian hydromyine rodents (Muridae) Journal of Zoology, London 209 607-629

Breed WG (1990) Copulatory behaviour and coagulum formation in the female reproductive tract of the Australian hopping mouse, Notomys alexis. Journal of Reproduction and Fertility 88 17-24

Breed WG (1997a) Interspecific variation of testis size and epididymal sperm numbers in Australasian rodents with special reference to the genus Notomys. Australian Journal of Zoology 45 651-669

Breed WG (1997b) Evolution of the spermatozoon in Australasian rodents Australian Journal of Zoology 45 459-478

Breed WG and Adams M (1992) Breeding systems of spinifex hopping mice (Notomys alexis) and plains rats (Pseudomys australis): a test for multiple paternity within the laboratory Australian Journal of Zoology 40 13-20

Breed WG and Sarafis V (1983) Variation in sperm head morphology in the Australian rodent, Notomys alexis. Australian Journal of Zoology 31 313-316

Breed WG and Taylor J (2000) Body mass, testes mass and sperm size in murine rodents Journal of Mammalogy 81 758-768

Breed WG and Washington JM (1991) Mating behaviour and insemination in the hopping mouse, Notomys alexis. Journal of Reproduction and Fertility 93 187-194

Clermont Y (1972) Kinetics of spermatogenesis in mammals: seminiferous epithelial cycle and spermatogonial renewal Physiological Reviews 52 198-236

Clermont $\mathbf{Y}$ and Trott $\mathbf{M}$ (1969) Duration of the cycle of the seminiferous epithelium in the mouse and hamster determined by means of ${ }^{3} \mathrm{H}$ thymidine and radioautography Fertility and Sterility 20 805-817

Clermont Y, Leblond CP and Messier B (1959) Durée du cycle de I'Èpithelium séminal du rat Archives D'Anatomie Microscopique et de Morphologie Experimentale 48 37-56

Courot M, Hochereau-de Reviers M-T and Ortavant R (1970) Spermatogenesis. In The Testis, Vol. 1 pp 339-432 Eds AD Johnson, WR Gomes and NL Vandemark. Academic Press, New York

Gebauer MR, Pickett BW and Swierstra EE (1974) Reproductive physiology of the stallion: II. Daily production and output of sperm Journal of Animal Science 39 732-736

Grocock CA and Clarke JR (1976) Duration of spermatogenesis in the vole (Microtus agrestis) and bank vole (Clethrionomys glareolus) Journal of Reproduction and Fertility 47 133-135

Harcourt AH, Harvey PH, Larson SG and Short RV (1981) Testis weight, body weight and breeding system in primates Nature 293 55-57

Johnson L, Petty CS and Neaves WB (1980a) A comparative study of daily sperm production and testicular composition in humans and rats Biology of Reproduction 22 1233-1243

Johnson L, Petty CS and Neaves WB (1980b) The relationship of biopsy evaluations and testicular measurements to overall daily sperm production in human testes Fertility and Sterility 34 36-40 
Johnson L, Petty CS and Neaves WB (1981) A new approach to the quantification of spermatogenesis and its application to germinal cell attrition during human spermiogenesis Biology of Reproduction 25 217-226

Kenagy GJ and Trombulak SC (1986) Size and function of mammalian testes in relation to body size Journal of Mammalogy 67 1-22

Leblond CP and Clermont Y (1952) Definition of the stages of the cycle of the seminiferous epithelium in the rat Annals of the New York Academy of Sciences 55 548-573

Noller DW, Flickinger CJ and Howards SS (1977) Duration of the cycle of the seminiferous epithelium in the guinea pig determined by tritiated thymidine autoradiography Biology of Reproduction 17 532-534

Okwun OE, Igboeli G, Ford JJ, Lunstra DD and Johnson L (1996) Number and function of Sertoli cells, number and yield of spermatogonia, and daily sperm production in three breeds of boar Journal of Reproduction and Fertility 107 137-149

Orgebin-Crist MC (1965) Passage of spermatozoa labelled with thymidine $-{ }^{3} \mathrm{H}$ through the ductus epididymidis in the rabbit Journal of Reproduction and Fertility 10 241-251

Orgebin-Crist MC (1967) Maturation of spermatozoa in the rabbit epididymis. Fertilizing ability and embryonic mortality in does inseminated with epididymal spermatozoa Annales de Biologie Animale, Biochimie et Biophysique 7 373-389

Orgebin-Crist MC (1968) Gonadal and epididymal sperm reserves in the rabbit: estimation of the daily sperm production Journal of Reproduction and Fertility 15 15-25

Oud JL and de Rooij DG (1977) Spermatogenesis in the Chinese hamster Anatomical Record 187 113-124

Peirce EJ and Breed WG (1987) Cytological organization of the seminiferous epithelium in the Australian rodents Pseudomys australis and Notomys alexis. Journal of Reproduction and Fertility 80 91-103

Peirce EJ and Breed WG (1989) Light microscopical structure of the excurrent ducts and distribution of spermatozoa in the Australian rodents Pseudomys australis and Notomys alexis. Journal of Anatomy 162 195-213

Peirce EJ and Breed WG (1990) Organization of testicular interstitial tissue of an Australian rodent, the spinifex hopping mouse, Notomys alexis. Cell and Tissue Research 260 469-477

Peirce EJ and Breed WG (1998) A pilot study to determine the validity of the optical disector method for cell quantitation in testes of Australian rodents Australian Mammal Society 1998 Conference Program and Abstracts A81

Robb GW, Amann RP and Killian GJ (1978) Daily sperm production and epididymal sperm reserves of pubertal and adult rats Journal of Reproduction and Fertility 54 103-107

Rosiepen G, Weinbauer GF, Schlatt S, Berhe HM and Nieschlag E (1994) Duration of the cycle of the seminiferous epithelium, estimated by the 5-bromodeoxyuridine technique, in laboratory and feral rats Journal of Reproduction and Fertility 100 299-306

Rowley MJ, Teshima F and Heller CG (1970) Duration of transit through the human male ductular system Fertility and Sterility 21 390-396

Russell LD, Ettlin RA, Sinha Hikim AP and Clegg ED (1990) Histological and Histopathological Evaluation of the Testis Cache River Press, Clearwater

Schuler HM and Gier HT (1976) Duration of the cycle of the seminiferous epithelium in the prairie vole (Microtus ochrogaster ochrogaster) Journal of Experimental Zoology 197 1-12

Short RV (1979) Sexual selection and its component parts, somatic and genital selection, as illustrated by man and the great apes Advances in the Study of Behaviour 9 131-158

Sinha Hikim AP, Maiti BR and Ghosh A (1985) Spermatogenesis in the bandicoot rat. I. Duration of the cycle of the seminiferous epithelium Archives of Andrology 14 151-154

Suttle JM, Moore HDM, Peirce EJ and Breed WG (1988) Quantitative studies on variation in sperm head morphology of the hopping mouse, Notomys alexis. Journal of Experimental Zoology 247 166-171

Watts CHS, Baverstock PR, Birrell J and Krieg M (1992) Phylogeny of the Australian rodents (Muridae): a molecular approach using microcomplement fixation of albumin Australian Journal of Zoology 40 81-90

Received 17 July 2000.

Accepted 18 September 2000. 